\title{
WHAT HAS DUNSMUIR TAUGHT?
}

\author{
Alice WOOLLEy AND SHAUn FluKeR*
}

\section{INTRODUCTION}

In Dunsmuir ${ }^{1}$ the Supreme Court of Canada reassessed the "troubling question" of how courts should review decisions of administrative tribunals. ${ }^{2}$ The majority judgment of Bastarache and LeBel JJ. (writing also for McLachlin, Abella, and Fish JJ.), sought to simplify the judicial review process by reducing the standards of review from three to two, increasing reliance on precedent to determine which standard is appropriate, making explicit the significance of the nature of the question to the determination of the standard in every case, and re-labelling the "pragmatic and functional" test the "standard of review analysis." In its recent judgment in Khosa ${ }^{4}$ the Supreme Court emphasized the simplifying intention of Dunsmuir, suggesting that "Dunsmuir teaches that judicial review should be less concerned with the formulation of different standards of review and more focused on substance, particularly on the nature of the issue that was before the administrative tribunal under review."

Reaction to Dunsmuir upon its release was mixed. While welcoming its attempt to address the ongoing problems within substantive judicial review, academic commentators suggested that it left some significant questions unresolved. Although Dunsmuir endorsed reliance on precedent for determining the appropriate standard of review, it did not resolve specific questions as to the nature of the precedent to be employed, such as "[h]ow closely must the facts and law be to previous judicial precedent for the doctrine of stare decisis to apply?” 6 That is, it did not indicate whether the precedent was required simply with respect to how categories of questions are to be treated when identifying the appropriate standard (as set out in, for example, Dunsmuir itself) or whether the relevant precedent required was that dealing with the particular decision-maker and the particular type of decision at issue. It also left open the possibility for an expanded use of "jurisdictional questions" in determining the appropriate standard of review. ${ }^{7}$ It further left open the possibility that almost nothing would change in the identification of the standard, given the majority's continued assertion of the significance of the pragmatic and functional analysis. ${ }^{8}$ With respect to the application of the standard, the decision did not clearly resolve whether "reasonableness" equated to a single type of deference, or whether within reasonableness review, and depending on the type of

Professors, Faculty of Law, University of Calgary.

Dunsmuir v. New Brunswick, 2008 SCC 9, [2008] 1 S.C.R. 190 [Dunsmuir].

Ibid. at para. 1.

Ibid. at para. 63.

Canada (Citizenship and Immigration) v. Khosa, 2009 SCC 12, [2009] 1 S.C.R. 339 [Khosa].

Ibid. at para. 4.

Ron Goltz, “'Patent Unreasonableness is Dead. And We Have Killed it.' A Critique of the Supreme Court of Canada's Decision in Dunsmuir,” Case Comment, (2008) 46 Alta. L. Rev. 253 at 259.

David Mullan, "Dunsmuir v. New Brunswick, Standard of Review and Procedural Fairness for Public Servants: Let’s Try Again!” (2008) 21 Can. J. Admin. L. \& Prac. 117 at 126-30 [Mullan, “Dunsmuir”]; Jared Craig, "Defending City Hall After Dunsmuir" (2008) 46 Alta. L. Rev. 275 at 290.

$8 \quad$ Alice Woolley, "The Metaphysical Court: Dunsmuir v. New Brunswick and the Standard of Review" (2008) 21 Can. J. Admin. L. \& Prac. 259 at 266. 
decision and/or decision-maker, varying forms of deference were appropriate. ${ }^{9}$ Further, if deference does not vary, how does a court then appropriately review decisions by administrative decision-makers that are not adjudicative tribunals, and whose decisions would normally have been subject to the highest level of deference ${ }^{10}$ Finally, it created some uncertainty in what a "reasonableness" review would consist of given that, on the Supreme Court's own standard, there was a rational argument that the arbitral decision under review in Dunsmuir was reasonable, yet that decision was overturned by the majority on a reasonableness standard. ${ }^{11}$

This case comment undertakes a preliminary analysis of whether Dunsmuir has fulfilled its simplifying aspirations, and of how problems with the decision identified by academic commentators have been resolved (or not). After a brief review of Dunsmuir in Part II, we turn in Parts III and IV to an analysis of judicial review decisions of the Alberta Court of Appeal from May 2008 to May 2009. In Part III we analyze trends in the identification of the standard of review, including whether the Alberta Court of Appeal has continued to rely on the pragmatic and functional analysis, its use of precedent, and its treatment of jurisdictional questions. We conclude that, in Alberta, straightforward reliance on the pragmatic and functional analysis has diminished. However, inconsistency exists with respect to the appropriate use of precedent and, in particular, as to whether precedent must be precisely on point or whether, once the nature of the question is identified, any binding precedent on how such questions should be reviewed, however otherwise distinct, is sufficient. It further appears that the Alberta Court of Appeal has firmly resisted any temptation to expand reliance on jurisdictional questions so as to justify less deferential review.

In Part IV we consider trends in the application of the standard of review, and in particular of the reasonableness standard. We conclude that the concerns identified by academics as to the application of the reasonableness standard in Dunsmuir were well founded. The Alberta Court of Appeal has rejected the argument that reasonableness can be treated as a spectrum; in so doing it has established law consistent with that of the Ontario Court of Appeal, ${ }^{12}$ but quite different from the British Columbia Court of Appeal, which has held that the level of deference to be employed is variable and contextual. ${ }^{13}$ Moreover, the Alberta decisions suggest that the Alberta Court of Appeal is not consistently comfortable with true deference. Like the majority of the Supreme Court itself in the Dunsmuir decision, ${ }^{14}$ in a number of cases the Court of Appeal, while asserting a need for deference, tends to review the issue before the administrative decision-maker in full, and then conclude whether the decision is reasonable based on its agreement or disagreement with the decision — as such, the reasonableness of the decision turns on its correctness. The majority decision in Dunsmuir stated that the test of reasonableness required assessing the "justification, transparency and

Mullan, "Dunsmuir,” supra note 7 at 134-36; Lorne Sossin, "Dunsmuir - Plus ça change” The Court (17 March 2008), online: The Court <http://www.thecourt.ca/2008/03/17/dunsmuir>. Mullan, "Dunsmuir," ibid. at 133.

Ibid. at 137-40.

The Ontario Court of Appeal has rejected the idea of "varying degrees of deference" on the grounds that it fails to comply with the simplifying objective of Dunsmuir: see Mills v. Ontario (Workplace Safety and Insurance Appeals Tribunal), 2008 ONCA 436, 237 O.A.C. 71 at para. 21 [Mills].

Teamsters Local Union No. 31 v. Shadow Lines Transportation Group, 2009 BCCA 130, 90 B.C.L.R. (4th) 74 at paras. 83-95 [Shadow Lines].

As noted by Mullan, "Dunsmuir," supra note 7 at 137-40. 
intelligibility within the decision-making process,"15 and considering “whether the decision falls within a range of possible, acceptable outcomes which are defensible in respect of the facts and law."16 Our review of the Alberta Court of Appeal decisions subsequent to Dunsmuir indicates, however, that even though the Court is deferential in result most of the time (in that the Court upholds the administrative decision), ${ }^{17}$ its review is in fact deferential far less often.

Based on this analysis, we recommend, inter alia, that when identifying the standard of review, a reviewing court should avoid becoming overly wedded to "tests," or even to precedent, and should focus on the point truly at issue in all modern substantive judicial review cases: given the nature of this question, who is best positioned to decide it, the court or the administrative decision-maker? ${ }^{18}$ The pragmatic and functional analysis, the Dunsmuir approach, and everything else are simply heuristics given to lower courts to enable them to think about these problems. We argue that the time has come for courts to, if not abandon heuristics, use them in conjunction with a direct consideration of the underlying problem. Equally, this may not result in simplification of the identification of the standard of review — it is impossible to simplify something innately complex — but it may result in a more transparent and effective grappling with the significant question of how courts and administrative decision-makers should interact in ensuring respect for the rule of law when implementing the mandates with which administrative decision-makers have been legislatively charged. Further, with respect to doing deference, we recommend that reviewing courts be more stringent in resisting the temptation to re-analyze the issue that was before the administrative decision-maker. Dunsmuir sets out a relatively clear methodology for how deference should be done and reviewing courts, including the Alberta Court of Appeal, have demonstrated the ability to do deference in this way. What is required is the discipline to avoid being more intrusive in review than this test contemplates. Part $\mathrm{V}$ considers the practical implications of these recommendations.

\section{DUNSMUIR}

Prior to Dunsmuir, the standard of review was determined by application of the "pragmatic and functional analysis" in every case. ${ }^{19}$ By the time the Supreme Court decided Dunsmuir in 2008, however, this approach had become increasingly unsatisfactory, appearing to be an overly mechanical, somewhat arbitrary, and unnecessarily complex methodology for deciding how much deference to afford to an administrative decision-maker.

A good illustration of this "arbitrary complexity" prior to Dunsmuir can be seen in the jurisprudence of the Alberta Court of Appeal with respect to selecting the standard of review to be applied to decisions of the then Alberta Energy and Utilities Board (EUB). In each case

Dunsmuir, supra note 1 at para. 47.

Ibid.

Twenty-nine of the 34 cases reviewed apply a deferential standard, and in 21 of those cases the administrative decision was undisturbed by the Court.

18 C.U.P.E. Local 963 v. N.B. Liquor Corporation, [1979] 2 S.C.R. 227; Nicholson v. Haldimand-Norfolk Regional Police Commissioner, [1979] 1 SCR 311; Knight v. Indian Head School Division No. 19, [1990] 1 S.C.R. 653 [Knight]; Pushpanathan v. Canada (Minister of Citizenship and Immigration), [1998] 1 S.C.R. 982 [Pushpanathan]; Baker v. Canada (Minister of Citizenship and Immigration), [1999] 2 S.C.R. 817. 
the Court of Appeal applied the four pragmatic and functional factors to determine the level of deference that should be afforded to the issues raised by the EUB decision in question. In each case, numerous factors relevant to that analysis remained the same, such as the existence of a statutory right of appeal coupled with a limited privative clause, and the EUB's significant expertise with respect to the technicalities, markets, and overall policies related to energy and resource development. The Court of Appeal was, however, willing to review EUB decisions based on standards of correctness, ${ }^{20}$ reasonableness, ${ }^{21}$ or patent unreasonableness ${ }^{22}$ depending on the nature of the question and the particular legislative provisions or common law principles at issue. This was not in itself a problem - the cases almost certainly merited different levels of deference. The problem was that the relationship between the standard of review selected, and the four part analysis of the pragmatic and functional analysis undertaken by the Court of Appeal, was opaque; it was difficult to see how the answer generated by the Court flowed from the analysis which preceded it. An answer could be speculated upon - as reflected here in the assertion that the nature of the question and the governing law was what had determined the answer - but could not be defended by anything expressly stated by the Court of Appeal itself.

In a variety of cases prior to Dunsmuir the Supreme Court had, to some extent, acknowledged this problem of arbitrary complexity. In such cases the Supreme Court focused, expressly or implicitly, significant attention on the nature of the question before the administrative decision-maker as crucial to determining the standard of review. ${ }^{23}$ This had not really resolved the problem, however, insofar as the Supreme Court had difficulty in a number of cases in achieving any agreement on the proper description of the nature of the question. Thus, in the 2001 Trinity Western University v. British Columbia College of Teachers $^{24}$ decision the issue was whether the British Columbia College of Teachers exceeded its jurisdiction by refusing to accredit Trinity Western University on grounds that the institution employed discriminatory policies. The majority of the Supreme Court accorded no deference to the College of Teachers, construing the College's decision as one concerning the legal scope of human rights protection - that is, a general question of law, arising in multiple contexts, and on which the judiciary can be considered to be highly expert. The dissenting justices, in contrast, construed the College's decision as concerning the management of the teaching profession in British Columbia, a highly specific question, one on which judges have no particular expertise, and therefore warranting significant judicial deference.

Other problems with judicial review pre-Dunsmuir existed. As recently identified by David Mullan in his review of the first ten years of the McLachlin court, the Supreme Court had become confused about the nature of a jurisdictional error - was such an error simply a product of the application of a standard of review analysis (that is, a patently unreasonable, unreasonable or incorrect decision), or was it an independent category of decision justifying 32.

ATCO Electric Ltd. v. Alberta (Energy and Utilities Board), 2004 ABCA 215, 361 A.R. 1 at para. 50. Ibid.

See e.g. ATCO Gas and Pipelines Ltd. v. Alberta (Energy and Utilities Board), 2006 SCC 4, [2006] 1 S.C.R. 140 at paras. 57-59 [ATCO Gas, S.C.C.].

2001 SCC 31, [2001] 1 S.C.R. 772. 
a particular approach to the identification of the standard of review ${ }^{25}$ Supreme Court justices were also divided about the ability of regulatory decision-makers to interpret their governing legislation, granting deference to decision-makers doing so in some cases, and none at all in others. Moreover, the legal community as a whole was significantly dissatisfied with the complexity and absence of predictability and clarity in the judicial review jurisprudence. All of these factors, Mullan argues, meant that the stability seemingly produced by the Supreme Court's decision in Pushpanathan was more apparent than real, and the Supreme Court began to drift inexorably to reconsideration of the pragmatic and functional test it had articulated there. ${ }^{26}$

Given these various issues, the view of the majority in Dunsmuir that the standard of review needed reconsideration, and that it was time to try and reduce "law office metaphysics" 27 in favour of paying attention to the substance of the matter before the courts, is explicable. The majority's solution to the problem was, as noted, to try and simplify both the method for selecting the appropriate standard of review, and the approach of the court when applying a standard of review, whether deferential or non-deferential.

The factual context of Dunsmuir was the Province of New Brunswick's dismissal, with pay in lieu of notice, of non-union employee David Dunsmuir. Dunsmuir grieved his dismissal on the basis of procedural unfairness and on the substantive grounds that he was in fact wrongfully dismissed for cause. Section 100.1 of the Public Service Labour Relations $A c t^{28}$ allowed non-union employees to grieve wrongful dismissal, and permitted an arbitrator to substitute a different penalty than discharge; Dunsmuir argued that since he was in fact dismissed for cause, he should have the benefit of that provision. Although not ultimately making a determination as to whether Dunsmuir had been dismissed for cause, a labour adjudicator held it was within an adjudicator's legislative authority to determine the true basis for the termination. He also decided that Dunsmuir had not been given sufficient procedural fairness in the termination process. He ordered Dunsmuir reinstated or, in the alternative, that he be paid eight months salary in lieu of notice.

Both the New Brunswick Court of Queen's Bench and the New Brunswick Court of Appeal held that the adjudicator's decision should not stand. Dunsmuir appealed to the Supreme Court of Canada, who dismissed his appeal. On the question of procedural fairness, the Supreme Court reversed the decision in Knight $^{29}$ that a public employee whose terms of employment are governed by contract can also claim a separate right to procedural fairness. ${ }^{30}$ On the substantive issue, it held that the labour arbitrator did not have the jurisdiction to determine the true basis for the termination; the Supreme Court split on the standard of review to be applied to this issue, but all agreed that the arbitrator's analysis was either incorrect or unreasonable, and could not stand.

David Mullan, “The McLachlin Court and the Public Law Standard of Review: A Major Irritant Soothed or a Significant Ongoing Problem?” in Adam Dodek et al., eds., Public Law at the McLachlin Court: The First Decade (Toronto: Irwin Law) [forthcoming].

Ibid.

Dunsmuir, supra note 1 at para. 122.

R.S.N.B. 1973, c. P-25.

Knight, supra note 18.

Dunsmuir, supra note 1 at para. 81 . 
For the majority, Bastarache and LeBel JJ. asserted that judicial review exists to ensure both the rule of law and respect for legislative supremacy: "[T]he rule of law is maintained because the courts have the last word on jurisdiction, and legislative supremacy is assured because determining the applicable standard of review is accomplished by establishing legislative intent." ${ }^{31}$ In order to accomplish these objectives, however, they held that the present system of judicial review must be simplified, both with respect to the "number and definitions of the various standards of review" and with respect to the "analytical process employed to determine which standard applies in a given situation.”32

With respect to the standards of review themselves, Bastarache and LeBel JJ. held that the standard of "patent unreasonableness" should be abandoned, and that courts should only apply either a standard of correctness or of reasonableness. To determine whether a decision is reasonable, the reviewing court must look both at the process for reaching the decision its "justification, transparency and intelligibility" — and at its substance — whether it "falls within a range of possible, acceptable outcomes which are defensible in respect of the facts and law." 33 Reasonableness is also about incorporating an attitude of deference — of taking seriously the deliberations, process and capacities of the administrative decision-maker with respect to the decision at issue. ${ }^{34}$ By contrast, in reviewing a decision for correctness, a court must simply answer the question itself and, from there, determine whether or not it agrees with the administrative decision; "[I]f not, the court will substitute its own view and provide the correct answer."35

With respect to the identification of the applicable standard, Bastarache and LeBel JJ. suggested that courts should not over-complicate the problem. In general, the nature of the issue or question in the case will largely determine the standard of review. ${ }^{36}$ Privative clauses tend to suggest the application of a reasonableness standard. Moreover, as often as not, prior jurisprudence can be relied on. To the extent more detailed consideration is required, the reviewing court can use the pragmatic and functional analysis, now called the "standard of review analysis.”

Justice Binnie accepted the majority's shift from the pragmatic and functional analysis; he disagreed with the majority, however, in two fundamental ways. First, he simplified even

$31 \quad$ Ibid. at para. 30. See also The Honourable Madam Justice Beverley McLachlin, "The Roles of Administrative Tribunals and Courts in Maintaining the Rule of Law” (1999) 12 Can. J. Admin. L. \& Prac. 171. As noted by David Mullan in his comment on Dunsmuir, (supra note 7, n. 26.), the contrast identified by the Court here is perplexing. The rule of law requires that all state action be lawful. The proper implementation of duly enacted legislation is lawful state action. There cannot therefore logically be tension between legislative supremacy and the rule of law. The problem is, rather, who determines whether legislation has been properly implemented on its terms, given the open-ended nature of such legislation? Should an administrative decision-maker decide, or the courts?

Dunsmuir, ibid. at para. 34.

Ibid. at para. 47.

Ibid. at paras. $48-49$.

Ibid. at para. 50 .

The majority and concurring opinions in Dunsmuir agree on emphasizing the nature of the question as the most important contextual factor in identifying the standard of review. It is noteworthy that this factor (nature of the question) is the only consideration in a standard of review analysis for which the judiciary has sole ownership in that the reviewing court alone decides the nature of the question at hand. In contrast, the other three Pushpanathan factors (privative clause/statutory right of appeal; relative expertise; and purpose of the legislation) are largely decided by the legislator in structuring the administrative regime. Thus, the emphasis by the Supreme Court on the nature of the question over the other three factors when identifying the standard of review arguably suggests less respect for legislative supremacy than the reasoning in Dunsmuir suggests on its face. 
more radically the initial step in identifying the standard of review. In his view the standard of review follows from identification of the nature of the question. Matters going to the administrator's scope of authority, matters of general law (that is, anything other than that which relates to the decision-maker's "home" statute), and matters of procedural fairness should always be subject to correctness review. Everything else should be subject to deferential review.

Second, while Binnie J. agreed with the majority that the standard of "patent unreasonableness" could be done away with, he rejected any implication that deferential review could take place on a "one size fits all" basis. Doing away with the artificial distinction between reasonableness and patent unreasonableness does not change the fact that ultimately some decision-makers — making some kinds of decisions — are entitled to more deference than other decision-makers - making other types of decisions - even if all fall within the "reasonableness" standard. ${ }^{37}$ Eliminating patent unreasonableness simply moves the problem from one existing between patent unreasonableness and reasonableness to one existing within reasonableness itself. ${ }^{38}$ To resolve this problem Binnie J. suggested that it is at this point — when it comes time to articulate how reasonableness will be applied — that the factors previously assessed through the pragmatic and functional analysis come into play. The level of deference dictated by those factors should, now, be used to dictate how much scrutiny a court applies to determine whether an administrative decision is reasonable. ${ }^{39}$

In her concurring judgment, Deschamps J. similarly suggested that the key in judicial review is to focus on the nature of the question at issue — "[v]ery little else needs to be done in order to determine whether deference needs to be shown to an administrative body." ${ }^{40}$ It is only if this analysis does not indicate the appropriate standard of review that the other factors in the pragmatic and functional analysis come into play. Justice Deschamps acknowledged that deference is difficult; while not following Binnie J.'s position that the degree of deference could be determined through the pragmatic and functional analysis, she suggested that "any context considered by a reviewing court will, more often than not, look more like a rainbow than a black and white situation." 41

\section{DUNSMUIR AND THE IDENTIFICATION OF THE APPROPRIATE STANDARD}

As discussed in the Introduction, commentaries written immediately subsequent to Dunsmuir raised issues with the decision's analysis of how to identify the standard of review - whether the pragmatic and functional analysis would remain the dominant methodology, how precedent was to be used, and whether jurisdictional questions would be resurrected as a determinative factor. This part analyzes the trends in the Alberta Court of Appeal's jurisprudence over the May 2008 to May 2009 period, looking in particular at the extent to which the pragmatic and functional (standard of review) analysis continues to be employed, how the Court has employed precedent, and how it has treated the issue of jurisdictional questions.

Dunsmuir, supra note 1 at paras. 135-36.

Ibid. at para. 139.

Ibid. at paras. 143-49.

Ibid. at para. 158.

Ibid. at para. 167. 


\section{A. Cases Using the Standard of ReVIEW AnAlysis}

Only eight of the 34 Court of Appeal decisions surveyed conducted a standard of review analysis for at least one issue raised by the application for judicial review. ${ }^{42}$ In those cases the application of the standard of review analysis appears unchanged from its former incarnation as the pragmatic and functional analysis. More specifically, it has the same arbitrary complexity of its predecessor: courts note where the different factors push deference - either to more or to less - and then state the applicable standard of review. A careful analysis of a judgment in light of other cases may provide a basis for viewing one factor as more significant than others in the court's consideration, but generally speaking reviewing a judgment's use of the standard of review analysis does not expressly reveal anything other than how each factor applies to the facts, whether a factor directs towards more or less deference, and the standard of review that court identifies as appropriate.

Thus in Bishop, ${ }^{43}$ the Court of Appeal considered an appeal by Dr. Bishop of a finding of misconduct in relation to billing infractions and, as well, the sanctions imposed upon him. Bishop was required to pay a fine but also the cost of his hearing and appeal, which amounted to over $\$ 70,000$, even though the fine itself was less than $\$ 10,000$. The Court applied the standard of review analysis to determine the applicable level of deference. The Court noted that there is a full right of appeal, which suggests less deference; the College has a role in standard setting and ensuring standards are upheld, which suggests more deference; and the questions were central to its jurisdiction and had a significant factual component, which suggests more deference. In the end, the Court held that review should be on the basis of reasonableness. Similar to the pragmatic and functional analysis, however, the Court gave no real explanation of why the statutory right of appeal factor weighed less than the others — is it because it is one factor pointing against deference while the other three point towards it, or is it because it is less significant or important? Likely the determinative factor was the nature of the question - that it was a question squarely within the jurisdiction of the administrative decision-maker and had significant factual components — but the Court did not expressly make that point in its analysis.

Other cases using the standard of review analysis could be analyzed similarly. The point to be made here is, simply, that the standard of review analysis does seem to have dramatically diminished in significance for the determination of the standard of review but, when it is used, it has the same issues as the pragmatic and functional analysis did previously. Workers, Local Lodge No. 99, 2009 ABCA 55, 448 A.R. 209 [Finning]; Stubicar v. Alberta (Office of the Information and Privacy Commissioner), 2008 ABCA 357, 440 A.R. 190; The Brick GP Ltd. v. Calgary (City of), 2008 ABCA 356, 440 A.R. 304 [The Brick]; Macdonald v. Mineral Springs Hospital, 2008 ABCA 273, 437 A.R. 7 [Macdonald]; Alberta (Securities Commission) v. Brost, 2008 ABCA 326, 440 A.R. 7 [Brost]; Alberta v. Alberta Union of Provincial Employees, 2008 ABCA 258, 433 A.R. 159 [A.U.P.E.]. 


\section{B. Cases using Precedent}

The majority of the Court of Appeal's decisions between May 2008 and May 2009 chose the standard of review on the basis of precedent. ${ }^{44}$ Perhaps not surprisingly, however, given the noted absence of direction in Dunsmuir with respect to how precisely stare decisis should operate in this context, the Court employed precedent in quite variable ways.

The most common approach was for the Court to look at past jurisprudence with respect to a particular administrative decision-maker and the particular decision under review. So in a number of cases the Court set out a list indicating the various kinds of questions that can come before this decision-maker, and indicating what prior case law had determined with respect to the applicable standard of review. In Gahir ${ }^{45}$ for example, the Court considered a decision by the Workers' Compensation Appeals Commission that the Workers' Compensation Board could find a worker able to work even where doctors had determined him to be permanently disabled, but that the Board had to identify suitable employment and had failed to do so in that case. With respect to the standard of review to be applied to Appeals Commission decisions, the Court held that prior cases indicate that questions of fact, credibility, and mixed fact and law decided by the Appeals Commission are to be reviewed for reasonableness, as are questions related to the interpretation and application of policies, interpretation of law within the Appeals Commission's expertise, and application of law. ${ }^{46}$ This precedent on how cases before the Appeals Commission are to be reviewed was determinative of the applicable standard of review, namely reasonableness.

This approach - of looking for closely related precedent to determine the standard of review - was in several cases taken to something of an extreme by the Court of Appeal. In those cases, the Court required that there be a prior decision exactly on point — dealing with this tribunal and this precise type of question - without which the Court would go on to the standard of review analysis. Thus in a Labour Relations Board case, Conrad J.A. ${ }^{47}$ used the standard of review analysis to identify the appropriate standard of review to be applied to a decision by the Board that Finning had violated a "statutory freeze" imposed on parties during collective bargaining by s. 147(3) of the Labour Relations Code. ${ }^{48}$ Justice Conrad held that since the parties could provide no "relevant jurisprudence relating to the degree of

ATCO Gas and Pipelines Ltd. v. Alberta (Energy and Utilities Board), 2009 ABCA 171, 454 A.R. 176; Sincennes v. Alberta (Energy and Utilities Board), 2009 ABCA 167, 454 A.R. 121 [Sincennes]; Ironside v. Alberta (Securities Commission), 2009 ABCA 134, 454 A.R. 285 [Ironside]; United Association of Journeymen and Apprentices of the Plumbing and Pipefitting Industry of the United States and Canada, Local 488 v. Bantrel Constructors Co., 2009 ABCA 84, 448 A.R. 194 [Bantrel]; Emeric Holdings Inc. v. Edmonton (City of), 2009 ABCA 65, 448 A.R. 31; Gahir v. Alberta (Workers' Compensation, Appeals Commission), 2009 ABCA 59, 448 A.R. 135 [Gahir]; Alberta (Securities Commission) v. Lavallee, 2009 ABCA 52, 446 A.R. 333 [Lavallee]; 587901 Alberta Ltd. v. Calgary (City of), 2009 ABCA 29, 446 A.R. 185; Brewer v. Fraser Milner Casgrain LLP, 2008 ABCA 435, 446 A.R. 76; Nortel Networks Inc. v. Calgary (City of), 2008 ABCA 370, 440 A.R. 325; United Food and Commercial Workers Union, Local 401 v. Westfair Foods Ltd. (The Real Canadian Superstore), 2008 ABCA 335, 440 A.R. 249 [Westfair Foods]; Brost, supra note 42 (considering both precedent and the standard of review analysis); Walsh v. Mobil Oil Canada, 2008 ABCA 268, 440 A.R. 199; Gimbel v. Alberta (Minister of Public Works, Supply \& Services), 2008 ABCA 262, 437 A.R. 175; United Food and Commercial Workers Union, Local 401 v. The Real Canadian Superstore, 2008 ABCA 210, 432 A.R. 212.

Gahir, ibid.

Ibid. at para. 13.

Finning, supra note 42. Justice Conrad was in dissent on the result but the majority judgment concurred in her identification of the applicable standard of review.

R.S.A. 2000, c. L-1. 
deference owed to the Board when interpreting the collective agreement for the purpose of applying section 147(3) of the Code," past jurisprudence could not determine the standard. ${ }^{49}$ This was a highly fact-specific rendering of the inquiry - Conrad J.A. was looking for a case involving both collective agreements and the particular legislative provision, without which the standard of review analysis has to be performed. Given the extensive jurisprudence on labour relations matters it seems likely that some related and helpful precedent, even if not precisely on point, could have been helpful to the inquiry and, quite likely, preclude the necessity for the standard of review analysis.

By contrast, in other cases the Court of Appeal has considered past jurisprudence much more generally, not with respect to the particular tribunal, but simply with respect to how past jurisprudence indicates that questions of the type before the Court should be reviewed. In Sincennes, ${ }^{50}$ the Court considered a decision by the EUB that it did not have jurisdiction to approve "alternate routes" for a transmission line outside the general corridor approved in a permit issued by the National Energy Board (NEB). Interveners challenged that decision and, as well, the EUB's interpretation of its "public interest" mandate in the context of approval of a commercial transmission line. Justice O’Brien identified the standard of review for these issues based on cases describing the appropriate standard of review for these types of issues; his judgment seemed unconcerned with whether the decisions related to this decision-maker or its legislative framework:

The standard of review with respect to the jurisdiction allocated to the NEB and EUB under the NEB Act is correctness. The Supreme Court of Canada in Dunsmuir... stated that "questions regarding the jurisdictional lines between two or more competing specialized tribunals [are] subject to review on a correctness basis".

The standard of review with respect to a tribunal's application of its public interest mandate is reasonableness; determination of what is in the public interest has been held to be a matter of administrative discretion and a formulation of opinion: Memorial Gardens Association Ltd. v. Colwood Cemetary Co.... To the extent, however, that the issue requires the determination of the test for what constitutes public interest, the standard of review is correctness.

In ATCO Gas Pipelines Ltd. v. AEUB ... the majority judgment examined the nature of public interest within the context of the standard of review, and observed at para. 31:

This question is undoubtedly one of law and jurisdiction. The Board would arguably have no greater expertise with regard to this issue than the courts. A court is called upon to interpret provisions that have no technical aspect.... The interpretations of general concepts such as "public interest" and "conditions" (as found in s. 15(3)(d) of the AEUBA) is not foreign to courts and is not derived from an area where the tribunal has been held to have greater expertise than the courts. ${ }^{51}$

The most extreme version of this approach is where the Court of Appeal barely used precedent at all. In Wachtler v. College of Physicians \& Surgeons (Alberta) ${ }^{52}$ the Court 
considered an appeal by a physician of a finding that he was guilty of professional misconduct in relation to his treatment of three patients, two of whom died of drug overdoses, and the imposition of a three month suspension, among other sanctions. The Court identified four different issues raised by the matter before it. It identified the appropriate standard of review for three of them on the basis of Dunsmuir alone; for the fourth it cited a single additional case related to the College:

\footnotetext{
The first issue advanced by Dr. Wachtler goes to the fairness of the Investigating Committee's process, and therefore to whether the Council applied the correct analysis in assessing the alleged breaches of procedural fairness. This is a question of general law, to be reviewed on the correctness standard: Dunsmuir at para. 60 . The second issue involves two questions: first, whether the Investigating Committee failed to apply the proper burden of proof is a question of general law, to which correctness applies: Dunsmuir at para. 60 . Second, whether the Investigating Committee, or the Council, applied the wrong standard of care is a question of mixed fact and law, where the legal and factual aspects cannot be easily separated. That question will be reviewed on the reasonableness standard: Dunsmuir at para. 53. Finally, the last ground of appeal involves the weighing of evidence, the exercise of discretion, and policy issues. It is therefore also reviewable on the reasonableness standard: Dunsmuir at para. 53; Litchfield v. College of Physicians \& Surgeons (Alberta) ... at para. $11 .^{53}$
}

Two further points about the use of precedent are worth noting. In two cases, the Court of Appeal appeared to use precedent not as an independent step in the analysis, but as part of how it applied the standard of review analysis. Thus in Border Paving, ${ }^{54}$ in which Border Paving appealed the Council's imposition of safety obligations after a workplace accident, the Court said that the past cases on decisions of the Council, which noted its expertise and function, suggested more deference, but the statutory right of appeal suggested less. Further, in Gift Lake Métis Settlement, the Court declined to rely on a relevant precedent, in part because it predated Dunsmuir. ${ }^{55}$

\section{True QUestions OF JURISDiction}

Despite the concerns of the various commentators, in none of the Court of Appeal's decisions did it identify issues as "true questions of jurisdiction," subject to correctness review. In fact, in several of the decisions the Court drew quite careful and fine distinctions to show how the question was not one of jurisdiction, although a superficial analysis could have let it seem that way. ${ }^{56}$ Thus in Macdonald, ${ }^{57}$ the issue under appeal was a decision by the Hospital Privileges Appeal Board that it had no jurisdiction to hear an appeal from an Operating Room Committee decision that it would not increase a physician's operating room time. This could quite easily have been characterized as a jurisdictional question — after all, the Appeal Board was deciding whether it has jurisdiction to do something. However, as the Court rightly pointed out, that is not sufficient to make something a jurisdictional question in the relevant sense. ${ }^{58}$ A jurisdictional question would be one that asks: can the Appeal

Ibid. at para. 13 .

Border Paving Ltd. v. Alberta (Occupational Health and Safety Council), 2009 ABCA 37, 446 A.R. 207

[Border Paving].

Gift Lake Métis Settlement, supra note 42 at para. 16.

Bantrel, supra note 44; Border Paving, supra note 54; A.U.P.E., supra note 42.

Supra note 42.

Ibid. at para. 27. 
Board even ask this question? Are they even entitled to decide whether they have the power to hear the appeal of the Operating Room Committee on this issue? That type of question was not raised. The Appeal Board does have that power, and the only question was as to the answer - could it hear the appeal or not? That question was a straightforward matter of statutory interpretation, and was properly reviewed by the Court on a reasonableness standard. ${ }^{59}$

\section{IDENTIFICATION OF THE STANDARD OF REVIEW IN ALBERTA POST-DUNSMUIR}

Based on this analysis, what conclusions can be drawn? Perhaps most notably, it is clear that the Dunsmuir endorsement of the use of precedent has liberated the Court of Appeal to, in some cases, dispose of the identification of the standard of review much more quickly. It has eliminated those cases where the Court would embark on a pro forma articulation of the pragmatic and functional analysis, pulling out a standard of review at the end without any expressly articulated relationship between that standard and the analysis just undertaken. The Court has also understood the point that true jurisdictional questions are rare, and has managed, even in difficult circumstances, to discern what constitutes such a question, and what does not. This gives some reason to believe that, post-Dunsmuir, the Court has been able to focus its attention more squarely on the substance of the matters before it rather than on the identification of the standard of review.

On the other hand, considerable confusion appears to reign as to just what it is that Dunsmuir has directed the Court of Appeal to do. There are some obvious errors — such as placing precedent within the standard of review analysis and not considering precedent where it predates Dunsmuir ${ }^{60}$ — but there are also inconsistencies in how the Court approaches the use of precedent. The Supreme Court perhaps needs to provide some direction as to just what it is that precedent is supposed to do and, in particular, as to the relationship between its statement at the beginning of Dunsmuir (and also by both Binnie and Deschamp JJ.) that certain questions should result in certain standards of review, and its suggestion that the standard should be determined by precedent. There is a significant difference between requiring precedent squarely on point — this tribunal dealing with this legislative provision - and simply looking at any case that provides direction on how this type of question should be reviewed. For the Court of Appeal to be doing one or the other, without any explanation as to why or on what basis it has chosen the precedent, creates a new layer of unpredictability in the analysis.

It is noted in this respect that other courts have also indicated some confusion on this point. In a leading British Columbia case, Shadow Lines, ${ }^{61}$ the British Columbia Court of Appeal dealt with an appeal by an employer of an arbitration award. In identifying the appropriate standard of review the Court on the one hand suggested that the effect of Dunsmuir was to indicate that past cases had settled how particular questions were to be treated for standard of review purposes, indicating that "if a question does not fall into one of the above outlined categories" ${ }^{\text {" }}$ then the standard of review analysis should be undertaken. 
On the other hand, in applying precedent to establish the standard of review in that case the Court did not assess the question relative to the categories in Dunsmuir, it assessed the question relative to other cases dealing with this type of decision-maker facing this type of decision. $^{63}$

Further, when the Alberta Court of Appeal applies the standard of review analysis, nothing has changed from the methodology as it existed prior to Dunsmuir. In those cases there is no discernible improvement in the approach. The number of cases in which the problem arises is reduced, but the fact of the problem has not gone away.

At the end of the day, identification of the standard of review requires courts to answer this basic question: given the nature of this question and this tribunal, who is in the best position to resolve it? If it is the tribunal, then the court should be deferential to the decision that the tribunal has made. If it is the court, then no such deference is appropriate. ${ }^{64}$ The use of precedent and the standard of review analysis are simply ways to sort out the best answer to this question. But they also, to some extent, avoid the very issue to be considered. Precedent may only be somewhat relevant, dealing either with questions that are not quite the same, or not dealing with this particular decision-maker. Yet if precedent is required to be squarely on point, it may only rarely generate an answer. The standard of review analysis can always be employed, but it also ultimately does not generate an answer in and of itself; the reviewing court imposes meaning on the analysis, it does not derive meaning from the analysis.

The advantage of heuristics - common sense rules to allow us to solve complex problems — is, always, that they make problems easier to think about, focusing consideration on the things of importance and eliminating extraneous details that can bog down the analysis. The disadvantage of heuristics is that they can also obscure what is really at issue, and occasionally lead to wrong answers. For example, a heuristic common to daily thinking is the "availability heuristic" — we derive answers to questions from the information that can quickly be brought to mind rather than from all of the information relevant to the question at issue. This makes decision-making easier and faster, insofar as it avoids the necessity of investigating information prior to making decisions. On the other hand, it tends to lead to bad mistakes where the information that is available is wrong or misleading. ${ }^{65}$

In the context of judicial review it may be worth retaining heuristics to help focus the analysis; however, reviewing courts should be clearly aware that that is all that they are doing when they look to precedent or look to the standard of review analysis. Precedent and

63 Another example of this approach can be seen in O'Hara v. Nova Scotia (Education), 2008 NSCA 62, 267 N.S.R. (2d) 64, in which the Nova Scotia Court of Appeal simply applied the standard of review analysis, without even acknowledging that precedent may have some relevance to the decision. In discussing Dunsmuir the Court of Appeal said, "While the concept remains basically the same, Dunsmuir suggests that this label [the pragmatic and functional analysis] should be abandoned" (para. 54).

$64 \quad$ Although it is arguable that even in those cases some respect for the administrative decision is warranted. See e.g. Alice Woolley, “'Practical Necessity’ or ‘Highly Sophisticated Opportunism’? Judicial Review and Rate Regulation After ATCO Gas and Pipelines Ltd. v. Alberta (Energy and Utilities Board)” (2006) 44 Alta. L. Rev. 445.

65 Richard H. Thaler \& Cass R. Sunstein, Nudge: Improving Decisions about Health, Wealth, and Happiness (New Haven:Yale University Press, 2008) at 24-26. 
standard of review analysis are common sense rules for answering a broader question, and that broader question remains as it has always been: who is best positioned to decide this question now before the court? The common sense rules produce answers to this question, but they do so indirectly, not directly, and they may also do so inaccurately when what those common sense rules direct the court to consider are not responsive to what is actually at issue. Part V will consider how framing the analysis to focus on the question more directly could affect judicial decision-making in practice.

\section{APPlying ReAsonablenESS - BeING DefERENTIAL}

As noted, Dunsmuir sets out a standard of reasonableness that requires a reviewing court to look at the process and substance of the administrative decision. ${ }^{66}$ The two questions remaining subsequent to Dunsmuir are: (1) After Dunsmuir, is there any variability in how deference should occur, or is deference a single standard to be applied to all administrative decisions? and (2) What does it mean in practice to assess the "justification, transparency and intelligibility within the decision-making process" and "whether the decision falls within a range of possible, acceptable outcomes which are defensible in respect of the facts and law"? ${ }^{67}$ This part assesses how the Alberta Court of Appeal has answered both of these questions.

\section{A. SPECTRUM OF DEFERENCE?}

The Court of Appeal has been unequivocal that there is no spectrum of reasonableness to be applied in reviewing administrative decisions. In International Association of Machinists and Aerospace Workers, Local Lodge No. 99 v. Finning International Inc. ${ }^{68}$ the Court considered a decision by the Labour Relations Board rejecting the union's application to treat Tracker Logistics Inc. as a successor employer when it entered into a contract to provide warehousing services to Finning. In resisting the application for judicial review Finning argued that, post-Dunsmuir, there should be a spectrum of deference, and that a decision of this sort was entitled to the highest possible level of deference. While agreeing that deference was appropriate, the Court rejected the concept of a "spectrum" of review: "The concept of a 'spectrum' of reasonableness ignores both the definition and the objective articulated by the Supreme Court of Canada.” ${ }^{69}$ In so deciding the Alberta Court of Appeal followed the Ontario Court of Appeal, ${ }^{70}$ but differed significantly from the British Columbia Court of Appeal. In Shadow Lines, ${ }^{71}$ the British Columbia Court of Appeal engaged in an extensive analysis of all three judgments in Dunsmuir, of the prior decision of the Supreme Court of Canada in Law Society of New Brunswick v. Ryan, ${ }^{72}$ and of the two key Supreme Court cases subsequent to Dunsmuir, Khosa, ${ }^{73}$ and Lake v. Canada (Minister of Justice). ${ }^{74}$ It concluded that while reasonableness itself may not move around on a spectrum, what reasonableness

Dunsmuir, supra note 1 at para. 47.

Ibid. at para. 47.

2008 ABCA 400, 446 A.R. 20.

Ibid. at para. 12 .

Mills, supra note 12.

Supra note 13.

2003 SCC 20, [2003] 1 S.C.R. 247.

Supra note 4.

2008 SCC 23, [2008] 1 S.C.R. 761. 
review looks like post-Dunsmuir is not the same as what it looked like before. In particular, in identifying the "range of possible outcomes" available to a decision-maker, the variability of that range will shift with the context:

I conclude from these comments that the 'range of acceptable outcomes' described by the new reasonableness test will be dictated by the nature of the question that the particular tribunal is required to examine. Here the question was fact driven, policy laden and discretionary. Thus, the range of outcomes was broad, and it was open to the Immigration Appeal Division to come to the conclusion that it did. ${ }^{75}$

This deviation between the provincial appellate courts makes it almost certain that, at some point, the Supreme Court will need to give further consideration to the variability of reasonableness review.

\section{B. APPLICATION OF DEFERENCE POST-DUNSMUIR}

No single case indicates the direction being taken by the Alberta Court of Appeal on deference. The jurisprudence must be assessed more broadly, and it must also always be kept in mind that being truly deferential is hard work. Simply put, in reviewing the decision of someone else it is very difficult to resist the temptation to impose your own view of matters.

Of the 34 Alberta Court of Appeal decisions reviewed for this comment, 29 applied the reasonableness standard to review the administrative decision. And of those 29 decisions, 21 found the administrative decision to be reasonable. These statistics suggest the Court of Appeal has adopted a deferential approach to substantive judicial review post-Dunsmuir. A closer look at how the Court actually conducts reasonableness review, however, suggests a more intrusive approach. That is, while the result suggests deference, the process through which the result is achieved does not.

In several cases that purported to apply reasonableness, the Court of Appeal deliberated over whether it agreed with the administrative decision. To borrow from Binnie J.'s caution in his concurring Dunsmuir opinion, ${ }^{76}$ in its reasonableness review the Court often reweighed the inputs that led to the administrative decision as if it were the Court's view of reasonableness that counts, rather than its identification of the outer boundaries of reasonable outcomes. This is subtly apparent in cases where the Court found the administrative decision to be reasonable, but did so by essentially agreeing with the administrative outcome. ${ }^{77}$

For example, the Court of Appeal's decision in Calgary (City of) v. Alberta (Municipal Government Board), ${ }^{78}$ involved a reasonableness review of the Municipal Government Board's decision that the Hudson's Bay Company was entitled to file a complaint to a city tax assessment on property (a shopping mall) in which the Bay is a tenant. The Board made

Shadow Lines, supra note 13 at para. 94.

Dunsmuir, supra note 1 at para. 141.

Additional decisions where the Court of Appeal seems to agree with the administrative decision, rather than defer to the administrative result as a reasonable outcome, include Deloitte \& Touche LLP v. Institute of Chartered Accountants of Alberta, 2008 ABCA 162, 433 A.R. 41; Ironside, supra note 44; Hennig v. Institute of Chartered Accountants of Alberta, 2008 ABCA 241, 433 A.R. 221; Westfair Foods, supra note 44; Finning, supra note 42; Lavallee, supra note 44; Gahir, supra note 44. 
its decision by interpreting applicable provisions of the Municipal Government Act, ${ }^{79}$ including the definition of "assessed person" in the legislation. While the Court of Appeal found the Board's decision to be reasonable, and was purportedly deferential, McFadyen J.A. effectively redecided the interpretive issue by applying various rules of statutory interpretation to the Municipal Government Act, ending with the conclusion that the Board's interpretation to include the Bay as an "assessed person" was "reasonable." 80 Perhaps the most telling hint from McFadyen J.A. that she would be deciding the matter for herself is in how she framed the issue for the Court: Does s. 460(3) of the Municipal Government Act limit the right of complaint about a property assessment to "the owner of the assessed property?" ${ }^{\prime 1}$ Rather than canvass the range of possible outcomes here, it seems McFadyen J.A. was intent from the outset to decide for herself whether the Board's decision was correct.

More obvious illustrations of an intrusive review that purported to be deferential can be found in cases where the Court of Appeal set aside the administrative decision as unreasonable. This is somewhat justifiable insofar as if the decision is unreasonable, and the Court intends to overturn it, the Court must give some explanation for its reasons for doing so. Having said that, though, the problem is that the Court in these cases does not so much explain why the decision is unreasonable - why it falls outside the range of possible outcomes, or is not intelligible, justifiable, or transparent — as it does explain why it views the decision as incorrect. Thus in Bantrel, ${ }^{82}$ the Court of Appeal quashed a labour arbitration panel decision that upheld an employer drug testing policy. The employer's policy was more stringent than that provided for in the applicable provisions of the collective agreement. In making its decision the arbitration panel considered the collective agreement, the drug testing policy incorporated into the collective agreement, and policy on employee drug testing generally. The panel's decision rested on its conclusion that the collective agreement drug testing provisions were not a complete code, and could be augmented by additional requirements. While the Court stated that it was applying reasonableness to review the panel's decision, ${ }^{83}$ the Court's subsequent application amounted, in essence, to a correctness review. After reviewing the panel's interpretation of the collective agreement guidelines, the Court bluntly stated its view that the panel incorrectly interpreted such guidelines to conclude they were not a complete code on drug testing: "In our view, the Panel incorrectly interpreted the Guideline.” ${ }^{\prime 4}$ Based on this view that the panel's interpretation was incorrect, the Court found no line of analysis in the panel's reasons to support its conclusion. ${ }^{85}$ In summary, the Court's decision that the panel's interpretation was incorrect led the Court to find the panel's decision to be unreasonable. There was no discussion as to whether the panel's decision was intelligible, justifiable, and transparent, and no discussion as to whether the panel's discussion fell within a range of outcomes. ${ }^{86}$

R.S.A. 2000, c. M-26.

Alberta M.G.B., supra note 78 at paras. 26-37.

Ibid. at para. 12 [emphasis in original].

Supra note 44.

Ibid. at paras. 29-30.

Ibid. at para. 37.

Ibid. at para. 42.

Other notable examples of the Court purporting to be deferential, but actually being quite intrusive were ATCO Gas and Pipelines v. Alberta (Energy and Utilities Board), 2008 ABCA 200, 433 A.R. 183 [ATCO Gas, C.A.]; A.U.P.E., supra note 42. In ATCO Gas the Court of Appeal considered a decision by the Board that an asset used solely for the purposes of revenue generation could nonetheless be considered to be "used or required to be used" and thus included in the utility's rate base. While the 
This is not to suggest that there were no instances where the Court of Appeal was truly deferential. Good examples of deference applied in the context of a reasonableness review include the Court of Appeal's decisions in Anderson v. Alberta Securities Commission, ${ }^{87}$ Craig, ${ }^{88}$ The Brick, ${ }^{89}$ and MacDonald. ${ }^{90}$ One common feature in each of these judgments is the relatively short length (at most, several paragraphs of text) of the Court's application of the reasonableness standard to the impugned administrative decision; generally finding that either the decision falls within a range of possible outcomes or that there was evidence to support the decision. For example, in Craig the Court of Appeal considered a decision of the Municipal District refusing to amend a by-law to permit a "kennel" as a discretionary use on property. It found that the District's decision was reasonable simply because its assertions of fact and policy were "supported by some evidence" a range of acceptable solutions.",92

Approaches of this sort are welcome, and to be encouraged. Occupying a position of deference is difficult. When someone, even someone to whom one is personally connected, like a spouse, does something with which one disagrees, it can be extraordinarily difficult to simply say, "well, it is not what I would have done, but it can be justified, and it is his/her decision to make." For courts to follow the mandate of Dunsmuir requires focusing on the concept of a range of solutions, and identification of whether the decision in question falls within that range, without a detailed exegesis of why the decision is not only reasonable, but also correct (or not only unreasonable, but also incorrect). ${ }^{93}$

\section{IMPLICATIONS}

Our review of the post-Dunsmuir decisions led to two key recommendations: (1) identification of the standard of review should focus directly on the fundamental question: given the nature of this question, who is best positioned to decide it, the court or the decisionmaker? and (2) deferential review should strongly resist re-litigation of the issue that was before the decision-maker, and should focus on the more general question of whether the decision can be rationally supported by the governing legislation.

Court of Appeal identified the applicable standard of review as "reasonableness" it critiqued the decision for internal inconsistency, for adopting an interpretation of "used" which the Court viewed as strained and for treating the generation of revenue as a "service," for not taking sufficient account of regulatory changes, and for placing too much emphasis on the asset's history rather than its future use (paras. 2328). The Court was, in other words, at some pains to demonstrate that the decision was incorrect. Similarly, in A.U.P.E. the Court applied a "reasonableness" standard to review a decision by the Labour Relations Board that it could scrutinize an employer's decision to dismiss a probationary employee to see if the decision was made in bad faith. The Court engaged in a detailed analysis of the terms of the collective agreement, the applicable legislation, and decisions from other jurisdictions to determine that the decision was "unreasonable." Interestingly, in doing so the Court upheld the decision of the Chambers Judge who had, in the initial review, applied a "correctness" standard. The Court of Appeal held that the appropriate standard was reasonableness but that the decision was unreasonable; in so doing it is not obvious that it engaged in review any more deferential than that of the Chambers Judge. 2008 ABCA 184, 437 A.R. 55.

Craig v. Bighorn (Municipal District No. 8), 2009 ABCA 119, 457 A.R. 221 [Craig].

Supra note 42.

Supra note 42.

Craig, supra note 88 at para. 7.

Ibid. at para. 8.

While significantly pre-dating Dunsmuir, the judgment of Wilson J. in National Corn Growers Assn. v. Canada (Import Tribunal), [1990] 2 S.C.R. 1324, perhaps best captures the essence of what it means for a reviewing court to be deferential, and deserves more attention than it has generally received in recent years. 
In this part we briefly consider the implications of these recommendations in practice. The second is the more straightforward, and will be dealt with first. As we noted in Part IV, there are many Alberta Court of Appeal decisions post-Dunsmuir that have adopted the appropriate attitude of deference, and the Supreme Court's identification of the relevant standard for reasonableness as whether a decision falls within a "range of possible outcomes" and is "justifiable, transparent and intelligible," gives clear direction for how deference should be done. The recommendation here is, therefore, not that reviewing courts should do something different, but that they should have the fortitude and discipline to be deferential when the law requires such.

The first recommendation is different, insofar as it urges courts to shift from the exclusive reliance on tests or precedent in identification of the standard of review, and towards considering who it is who should be deciding the particular question at hand. What would focusing on this more fundamental aspect do in practice? In our view its effect would be to better achieve the simplifying goal set out in Dunsmuir, and to eliminate the metaphysics unleashed by an attempt to generate a single answer from a four part test that generates not only different answers, but answers in opposition to one another. Consider, for example, one of the notable judicial review cases heard by the Supreme Court that immediately preceded Dunsmuir: ATCO Gas. ${ }^{94}$ In ATCO Gas the Supreme Court identified the standard of review using the pragmatic and functional analysis. The result of so doing was however to result, first, in different standards of review being used by the majority and the dissent and, second, to result in both judgments arguably missing the significant point for a court faced with reviewing a decision about what a utility regulator should do when a utility disposes of an asset which has been included in rate base. That decision involved two basic things. First, it involved an understanding of the facts and policy surrounding utility rate regulation, which are notoriously complex, involve far more economics than law, and about which there can be no question the regulator knows infinitely more than the members of a court. Second, it involved interpretive questions around the legislative grant of authority given to the regulator. These are matters about which, even though that legislation is the "home" statute of the regulator, the courts are better positioned to assess than the regulator. Judicial review in that case should, therefore, simply have recognized that on the first issue the court should defer to the judgment and information provided by the regulator, and on the second issue it should not. Had it done so then the result in the case may (or may not) have been the same; what would have been avoided was some of the significant errors that were made by the majority with respect to the functioning of utility rate regulation (most notably that a utility company bears the downside risk associated with asset ownership) while also avoiding some of the less than compelling legal analysis undertaken by the Board (that a broad "public interest” mandate, and a requirement for Board approval prior to disposition of an asset, allowed rate setting to occur outside of a rate hearing, and with no attention to other relevant principles such as the rule against retroactive rates). What also would have been avoided was any significant time being spent on the identification of the applicable "standard."

The practical difficulties with this approach are that it does not give much guidance to lower courts, it has less ability to constrain judges who are inclined to be undisciplined in their thinking about such matters, and it has the potential to lead to inconsistent approaches 
to similar issues or decisions. It is for this reason that we do not advocate abandoning the type of common sense rules that the Supreme Court has attempted to articulate over the past few years. Our point is, simply, that those heuristics should not become a reason to overcomplicate the analysis or - and more importantly — to miss what is really required to review an administrative decision so as to protect the rule of law and ensure that administrative decision-makers are able to exercise their legislative grant of authority.

\section{CONCLUSION}

The cases of the Alberta Court of Appeal reviewed for this case comment indicate that the job of the Supreme Court of Canada in clarifying substantive judicial review is not yet done. How courts are to use precedent to identify the standard requires significant clarification, as does the question of whether reasonableness review is variable and contextual, or fixed. Further, the Supreme Court needs to continue to elaborate what doing deference looks like so that lower courts can find the discipline to be truly deferential when deference is what is required. Finally, the Supreme Court needs to help lower courts use decision-making heuristics to help think through the problem in a disciplined way without losing sight of the fundamental issue in any substantive judicial review case: What is the question at hand, and who is best fit to decide it? 